\title{
Leaf anatomical features and their implications for the systematics of dragon's blood, Croton section Cyclostigma (Euphorbiaceae)
}

\author{
ANA CARLA FEIO ${ }^{1,2}$, RENATA M. S. A. MEIRA ${ }^{1 *}$ and RICARDA RIINA ${ }^{3}$ \\ ${ }^{1}$ Programa de Pós-graduação em Botânica, Departamento de Biologia Vegetal, Anatomia Vegetal, \\ Universidade Federal de Viçosa, Viçosa 36570-900, Brazil \\ ${ }^{2}$ Programa de Capacitação Institucional, Coordenação de Botânica, Museu Paraense Emílio Goeldi, Av. \\ Perimetral, Montese, CEP 66077-830, Belém, PA, Brazil \\ ${ }^{3}$ Real Jardín Botánico, RJB-CSIC, Plaza de Murillo 2, 28014 Madrid, Spain
}

Received 22 March 2017; revised 20 February 2018; accepted for publication 18 May 2018

\begin{abstract}
Establishing species limits in clades in Croton using characters from external morphology and common molecular markers has proved cumbersome, especially in Croton section Cyclostigma, a group of 50 Neotropical arborescent species commonly known as dragon's blood. Given this, we explored leaf and shoot apex anatomical characters for their utility in distinguishing species or groups of species in this section. We analysed 90 specimens belonging to section Cyclostigma and 14 specimens from related groups (sections Adenophylli, Cupreati and Sampatik), recording and describing 45 qualitative leaf characters. These characters were assembled into a matrix and analysed using statistical clustering methods based on similarity. Our results show that trichomes are one of the most diverse and variable anatomical features among the studied specimens. Novel anatomical features for Croton include the presence of a hypodermis and two previously unreported types of non-glandular trichomes. Although we did not detect a single anatomical character uniting section Cyclostigma, combinations of anatomical characters were useful to establish species limits and taxonomic identities within this section.
\end{abstract}

ADDITIONAL KEYWORDS: colleters - hypodermis - idioblasts - nectaries - non-articulated laticifers - nonsecretory trichomes.

\section{INTRODUCTION}

Croton L. is a megadiverse genus with $>1200$ species (Christenhusz, Fay \& Chase, 2017; Haber et al., 2017). The medicinally important dragon's blood trees belong exclusively to Croton section Cyclostigma Griseb. (Riina, Berry \& van Ee, 2009), one of the main Neotropical clades of the genus. About 750 species in the genus occur in the New World, and these are organized into 31 sections in the most recent classification (van Ee, Riina \& Berry, 2011). According to ongoing taxonomic studies, section Cyclostigma consists of $c .50$ species distributed from Mexico to northern Argentina (Riina et al., pers. comm.). All species in this section produce abundant reddish to orange/yellowish latex, which is widely used in many Latin American countries, mainly

*Corresponding author. E-mail: rmeira@ufv.br as a treatment for skin wounds and burns (Meza, 1999; Borges \& King, 2000; Jones, 2003; Salatino, Salatino \& Negri, 2007). Dragon's blood trees grow predominantly in moist forests, including riverine, lowland and montane forests, but a few species occur in dry forests (van Ee et al., 2011).

Like the other 30 sections of New World Croton, section Cyclostigma is monophyletic. However, the resolution of the relationships between and within most sections is still a work in progress. For instance, a monophyletic section Cyclostigma was established by excluding several putative species, which were retrieved in seven other clades of Croton. The Cyclostigma clade is sister to the monotypic section Cupreati Riina in the phylogenetic analysis based on $\operatorname{trnL}-F$ or sister to section Adenophylli Griseb. (section Cascarilla in Riina et al., 2009) in the ITS tree. In addition, resolution at the species level in the 
Cyclostigma clade was low and many dragon's blood species remained to be sampled (Riina et al., 2009).

The only potential synapomorphy for section Cyclostigma is the presence of non-articulated laticifers in wood rays (Wiedenhoeft, Riina \& Berry, 2009). On the other hand, all species in the section share a suite of morphological characteristics including arborescent habit, reddish latex, stellate indumentum, conspicuous stipules, acropetiolar glands, long thyrsoid inflorescences with bisexual cymules predominantly at the base and staminate flowers with $>16$ stamens (Riina et al., 2009). However, most of the individual characters from the suite described above are also present in other clades of Croton (van Ee et al., 2011).

Although recent taxonomic studies of the dragon's blood group have identified new and morphologically distinct species (Riina, Berry \& Cornejo, 2007; Riina, Vigo \& Cerón, 2014; Riina et al., 2015; Feio et al., in press), establishing species limits in section Cyclostigma has proved difficult due to the prevalent homoplasy in most of the traditional morphological characters and the lack of resolution at the species level with the molecular markers used so far (Riina et al., 2009; van Ee et al., 2011).

Given this scenario, we conducted a comparative analysis of leaf anatomical features using a broad sampling of section Cyclostigma, a selection of species from its sister clades from nuclear and plastid phylogenetic analyses (sections Adenophylli and Cupreati) and a representative of a more distant clade [section Sampatik (G.L.Webster) Riina]. Our goals were to identify additional anatomical features that could help to tease apart species or groups in section Cyclostigma and to expand the database of characters available for studies of morphological evolution in Euphorbiaceae.

\section{MATERIAL AND METHODS}

\section{TAXON SAMPLING}

We sampled 104 specimens, of which 90 belong to Croton section Cyclostigma or have morphological affinities with that section according to ongoing taxonomic studies (R. Riina, pers. comm.), 11 specimens representing six species were from Croton section Adenophylli, one specimen from the only known species (C. cupreatus Croizat) of section Cupreati and two specimens of $C$. piptocalyx Müll.Arg. from section Sampatik. Specimens were identified to section based on their morphological affinities according to van Ee et al. (2011). Plant material for anatomical studies was obtained from herbarium specimens (Appendix 1). Herbarium acronyms follow those of Thiers (2016, continuously updated).

\section{LIGHT MICROSCOPY}

Herbarium samples of fully expanded leaves and shoot apex were rehydrated (Smith \& Smith, 1942) and stored in $70 \%$ ethanol. Subsequently, fragments from the middle and basal portions of the leaf blade (midrib and margin) and the middle and distal portions of the petiole were dehydrated in decreasing ethanol series and were embedded in 2-hydroxyethyl methacrylate resin for sectioning (Historesin Leica $§$, solutions were prepared according to manufacturer's instructions) following Meira \& Martins (2003). All samples were transversally and longitudinally sectioned with a thickness of 3-7 $\mu \mathrm{m}$, using an automatic rotary microtome (model RM 2265, Leica® Biosystems, Nussloch GmbH, Heidelberg, Germany) using disposable glass knives (Leica®, Biosystems, Nussloch $\mathrm{GmbH}$ ). Sections were stained with toluidine blue at pH 4.6 (O'Brien, Feder \& McCully, 1965) and slides were mounted in resin (Permount $\circledast$, Fisher Scientific, NJ, USA).

Some of the samples were also cleared with 5\% sodium hydroxide and $20 \%$ hypochlorite solutions, stained with $50 \%$ ethanol-diluted fuchsin (Shobe \& Lersten, 1967) and mounted in glycerinated gelatin (Kaiser, 1880).

Observations and photographic documentation were performed with a light microscope (Model AX70TRF, Olympus Optical, Tokyo, Japan) equipped with a U-Photo system, polarizing filter and digital camera (AxioCam HRc; OCarl Zeiss, Jena, Germany). Macro images were obtained using a stereomicroscope (Stemi 2000-C®, (C) arl Zeiss Microscopy GmbH, Jena, Germany) with a coupled digital camera (AxioCam ERc5s®, @Carl Zeiss Microscopy GmbH, Jena, Germany).

\section{SCANNING ELECTRON MICROSCOPY}

Some of samples stored in $70 \%$ ethanol were dehydrated in ethanol and critical point dried with $\mathrm{CO}_{2}$ (Bozzola \& Russel, 1992) in a 020 CPD dryer (Bal-Tec; Balzers, Liechtenstein). They were mounted on aluminium stubs and coated with gold using a FDU 010 sputter coater (Bal-Tec). Examination of specimens and image capture were conducted using a scanning electron microscope Leo 1430VP (Zeiss, Cambridge, UK) at the Centro de Microscopia e Microanálises, Universidade Federal de Viçosa.

\section{DESCRIPTION AND ANALYSIS OF ANATOMICAL CHARACTERS}

Anatomical descriptions were based on terms from Metcalfe \& Chalk $(1979,1983)$ and Evert (2006). Trichome terminology followed the classification of 
Webster, Del-Arco Aguilar \& Smith (1996). Forty-five qualitative characters from leaf and shoot apex were recorded (Table 1). A matrix of specimens by characters was built, in which characters were coded as binary states (Appendix 2). A distance matrix was calculated using the Dice-Sorensen and Jaccard coefficients and similarity dendrograms were generated using the software PAST3 vs. 3.06 (Hammer, Harper \& Ryan, 2001). The resulting dendrograms were further edited in FigTree vs.1.4 (Rambaut, 2012) and CorelDRAW X3 ${ }^{\circledR}$.

The taxonomic identity of the specimens was confirmed or modified by integrating information from the resulting clustering pattern, morphology from taxonomic descriptions, field observations, type specimens, habitat and geographical distribution.

\section{RESULTS}

\section{LEAF ANATOMY}

The matrix of anatomical characters has $1.3 \%$ of missing data coded as '?' (Table 2). There were 17 specimens (Table 2), for which we could not evaluate some characters (1-11) because the original herbarium material was too old or poorly preserved. In section Cyclostigma the most critical specimens regarding missing data were C. bogotanus Cuatrec. (Riina-1591) and C. mutisianus Kunth (Barkley-3768), both with the maximum percentage of missing characters $(21 \%)$ (Table 2).

Of all the surveyed characters, trichomes were the most diverse and variable and may differ even between closely related species (Fig. 1A-O), but no type was exclusive to section Cyclostigma or any of the other outgroup species. Non-glandular trichomes were lepidote (Fig. 1A, B), dendritic (Fig. 1C, D), rosulate (Fig. 1E, F), fasciculate cushion-shaped (Fig. 1G, H), stipitate-stellate (Fig. 1I), stipitate-stellate porrect (Fig. 1J), appressed-stellate porrect (Fig. 1K), appressedstellate (Fig. 1L), multiradiate (Fig. 1M, N) or simple (Fig. 1O). Out of these tn types, only the rosulate, stipitate-stellate porrect, appressed-stellate porrect and simple types are more typical of section Cyclostigma.

Lepidote trichomes [present in two specimens (C. urucurana Baill. -1) of section Cyclostigma and in sections Adenophylli (C. ruizianus Müll.Arg.) and Cupreati (C. cupreatus)], dendritic trichomes [present in C. vulnerarius Baill. -2, C. draco Schltdl. -1, and C. celtidifolius Baill. -1] and fasciculate cushion-shaped trichomes [present in C. huberi Steyerm., C. speciosus Müll.Arg., C. medusae Müll.Arg. -1, C. medusae-4 and C. coriaceus Kunth -3] were less common.

All specimens present hypostomatic leaves with parasitic stomata (Fig. 2A-C), epidermis with sinuous anticlinal walls on the abaxial side (Fig. 2A, B), straight to slightly sinuous walls on the adaxial side (Fig. 2C) and a slightly striated cuticle covering the epidermis on both sides (Fig. 2B). In cross section, they present a single-layered epidermis, thin cuticle, and stomata placed at the same level of the ordinary epidermal cells (Fig. 2D, E). In some specimens of section Cyclostigma (C. amentiformis Riina, C. bogotanus, C. coriaceus-2, C. coriaceus-3, C. floccosus B.A.Sm., C. rimbachii Croizat) and in section Cupreati, we observed a singlelayered hypodermis underlying the adaxial epidermis (Fig. 2D).

The mesophyll is dorsiventral in all specimens, with one or two layers of palisade parenchyma and four or five layers of spongy parenchyma (Fig. 2D, E). The vascular system is formed by collateral bundles (Fig. 2E), which possess bundle-sheath extensions only in sections Cyclostigma and Cupreati (Fig. 2D). Under polarized light, we detected abundant druse crystals in all the studied specimens, but they are found mostly in the ground parenchyma of different regions of the blade (Fig. 2F).

Leaf margins are predominantly revolute (Fig. 2G, inset); however, in section Cyclostigma there are specimens with a slightly involute margin (Fig. 2H, inset) as in C. bogotanus, C. draco-2, C. echinocarpus Müll.Arg., C. erythrochilum Müll.Arg., C. erythrochyloides Croizat, C. floccosus and Riina1416. Leaf margins can also present either continuous (Fig. 2G, H) or discontinuous (Fig. 2I) palisade parenchyma.

The midrib is biconvex (Fig. 2J) in sections Cyclostigma, Cupreati and Sampatik and C. abutilifolius Croizat and C. gracilipes Baill. (section Adenophylli) and uniconvex with the adaxial side flat to slightly concave in C. conduplicatus Kunth and C. ruizianus (section Adenophylli) (Fig. 2K). Sections Cyclostigma and Adenophylli possess a midrib with five to ten layers of angular-annular collenchyma (Fig. 2J, L) and a continuous palisade parenchyma (Fig. $2 \mathrm{~K}, \mathrm{~L}$ ), but the palisade parenchyma is not continuous in species of sections Cupreati and Sampatik. In all the studied species, except C. aequatoris Croizat and C. conduplicatus in section Adenophylli, the vascular system consists of collateral bundles arranged in a main open arch and one to five smaller dorsal bundles and all bundles are surrounded by fibres (Fig. 2J, L, M). In contrast, C. aequatoris and C. conduplicatus are the only species with a single main vascular bundle (Fig. 2K).

In all specimens, the petiole in cross section is rounded with a slight depression in the central region of the adaxial side (Fig. $2 \mathrm{~N}$ ). The epidermis is single-layered with tiny cells (Fig. 2O) and covered by a thin cuticle. In the cortical region, nine or ten layers of angular collenchyma are present underlying the epidermis, followed by seven to ten layers of 
Table 1. Qualitative anatomical characters used in cluster analysis coded as present (1) or absent (0) in the matrix

\begin{tabular}{|c|c|}
\hline Number & Character and states \\
\hline $\mathbf{1}$ & Secretory idioblasts \\
\hline 2 & Hypodermis \\
\hline 3 & Continuous palisade parenchyma in the midrib \\
\hline 4 & Bundle-sheath extension \\
\hline 5 & Margin with continuous palisade parenchyma \\
\hline 6 & Colleters on the leaf margin \\
\hline 7 & Basilaminar/acropetiolar colleters \\
\hline 8 & EFNs basilaminar \\
\hline 9 & EFNs acropetiolar \\
\hline 10 & EFNs dispersed on the blade \\
\hline 11 & EFNs marginal \\
\hline 12 & EFNs sessile \\
\hline 13 & EFNs stipitate \\
\hline 14 & EFNs with concave surface \\
\hline 15 & EFNs with convex surface \\
\hline 16 & EFNs with flat surface \\
\hline 17 & Lepidote trichomes \\
\hline 18 & Rosulate trichomes \\
\hline 19 & Dendritic trichomes \\
\hline 20 & Fasciculate cushion-shaped trichomes \\
\hline 21 & Stipitate-stellate trichomes \\
\hline 22 & Stipitate-stellate porrect trichomes \\
\hline 23 & Appressed-stellate porrect trichomes \\
\hline 24 & Appressed-stellate trichomes \\
\hline 25 & Multiradiate trichomes \\
\hline 26 & Fasciculate trichomes \\
\hline 27 & Simple trichomes \\
\hline 28 & Hypostomatic leaf \\
\hline 29 & Amphistomatic leaf \\
\hline 30 & Paracytic stomata \\
\hline 31 & Secretory idioblasts only in the abaxial epidermis \\
\hline 32 & Secretory idioblasts only in the adaxial epidermis \\
\hline 33 & Secretory idioblasts in both abaxial epidermis and palisade parenchyma \\
\hline 34 & Secretory idioblasts in the palisade parenchyma \\
\hline 35 & Secretory idioblasts dispersed in the mesophyll \\
\hline 36 & Non-articulated branched laticifers \\
\hline 37 & Articulated laticifers \\
\hline 38 & Unistratified epidermis \\
\hline 39 & Dorsiventral mesophyll \\
\hline 40 & Biconvex midrib \\
\hline 41 & Midrib uniconvex, with flat to slightly concave adaxial face \\
\hline 42 & Midrib with colateral bundles arranged in an open arch-like with one to five dorsal bundles \\
\hline 43 & Midrib with colateral bundles arranged in an open arch-like without dorsal bundles \\
\hline 44 & Revolute margin \\
\hline 45 & Involute margin \\
\hline
\end{tabular}

parenchyma. The collateral vascular system presents horseshoe-shaped and two accessory bundles, with fibres in the perivascular region (Fig. 2O). In the adaxial face, adjacent to the main vascular bundle, there are two accessory bundles surrounded by fibres (Fig. 2P).

\section{SECRETORY STRUCTURES}

We identified four types of secretory structures with different topology and histological organization distributed in all studied specimens. These were idioblasts, laticifers, colleters and extrafloral nectaries (EFNs). 
Table 2. Specimens with missing data in the leaf character matrix and their respective numbers and percentage. Total number of characters coded is 45 , and total number of cells in the matrix is 5408 (45 characters $\times 104$ specimens)

\begin{tabular}{lcc}
\hline Specimens (Voucher) & \# missing characters & \% missing characters \\
\hline C. aequatoris (Riina-1434) & 6 & 12 \\
C. bogotanus (Riina-1591) & 11 & 21 \\
C. bonplandianus (Riina-1517) & 10 & 19 \\
C. conduplicatus (Riina-1296) & 6 & 12 \\
C. hibiscifolius (Breteler-3446) & 4 & 8 \\
C. hibiscifolius (Contreras-042) & 2 & 4 \\
C. mutisianus-2 (Barkley-3768) & 11 & 21 \\
C. piptotocalyx (Bortoluzzi-379) & 2 & 4 \\
C. pseudopopulus (Mota-2276) & 1 & 2 \\
C. pseudopopulus (Mota-2284) & 1 & 2 \\
C. pseudopopulus (Mota-2291) & 1 & 2 \\
C. rimbachii (Riina-1402) & 3 & 6 \\
C. rusbyi (Riina-1479) & 1 & 2 \\
C. rusbyi (Riina-1481) & 1 & 2 \\
C. urucurana-1 (Leitão-Filho-1603) & 3 & 6 \\
C. urucurana-1 (Pollito-VA 001) & 5 & 10 \\
C. vulnerarius-1 (Forero-8148) & 2 & 4 \\
Total (entire matrix) & $\mathbf{7 0}$ & $\mathbf{1 . 3}$ \\
\hline
\end{tabular}

Secretory idioblasts were common in all specimens, and consist of large cells, sometimes strongly stained due to the secretion accumulated inside the vacuole. They were located in the abaxial epidermis (Fig. 3A) and scattered in the mesophyll (Fig. 3B) in most specimens of section Cyclostigma and in all specimens of sections Adenophylli and Sampatik. In section Cupreati, idioblasts were present both in the abaxial epidermis and palisade parenchyma (Fig. 3C), and present only in the palisade parenchyma (Fig. 3D) in C. pseudopopulus Baill., C. floccosus, Riina-1416 and C. urucurana-1. Some idioblasts were situated on the stipe of trichomes (Fig. 3E) in some specimens from all sampled sections, but the presence of these structures in specimens with stipitate trichomes did not show a consistent pattern within species.

The shoot meristems of all specimens examined presented laticifers dispersed in ground tissues of leaves, which exhibited a ' $\mathrm{Y}$ ' branching pattern (Fig. $3 \mathrm{~F}-\mathrm{H}$ ) and evident secretory activity. These laticifers appear to be non-articulated, although the anatomical preparations from the herbarium material used did not allow a clear enough visualization of the pattern of cellular division to be totally confident about the laticifer type.

Colleters occurred exclusively along the leaf margin of all analysed specimens, and they were of the standard type (Fig. 3I), non-vascularized, with a secretory epidermis with a single-layered, radially arranged palisade and a thin cuticle. They have a slightly constricted base and a central axis composed by fundamental parenchyma where secretory idioblasts, druse crystals and laticifers can be present. In fully expanded and mature leaves, colleters eventually fall off with age and they are regarded as deciduous.

Extrafloral nectaries were also present in all specimens. They were located either at the base of the leaf blade (basilaminar) (Fig. 3J) or at the distal portion of the petiole (acropetiolar) (Fig. 3K, L). Acropetiolar or basilaminar EFNs were usually in one pair. There were EFNs dispersed on the blade (Fig. 3M) and along the leaf margin (Fig. $3 \mathrm{~N}$, inset) only in C. piptocalyx (section Sampatik). The only specimens in section Cyclostigma with more than two acropetiolar and basilaminar EFNs were C. redolens Pittier, C. pseudopopulus and medusae-1 (Carvalho-3789) (Fig. 3O, P). EFNs varied among and within species from sessile (Fig. 3L-O) to stipitate (Fig. 3J, K, P), and their secretory surface can be concave (Fig. 3Q, R), convex (Fig. 3S) or flat (Fig. 3T). Croton piptocalyx was the only species with EFNs scattered over the abaxial side of the blade near the margins (Fig. 3M), the apex of the petiole and alternating with colleters along the margins (Fig. 3N). Basilaminar and acropetiolar EFNs were similar in their structure and were present in all species sampled (Fig. 3Q-T). They consist of a single-layered palisade secretory epidermis, a dense protoplast and a smooth and thick cuticle. Underlying the secretory epidermis, there were ten to 12 layers of nectariferous parenchyma of isodiametric cells with dense cytoplasm, containing druse crystals, secretory idioblasts and laticifers. EFNs were vascularized by bundles originating from the blade and/or the petiole and consisting of both xylem and phloem, but with the latter being more abundant (Fig. 3Q, T). 

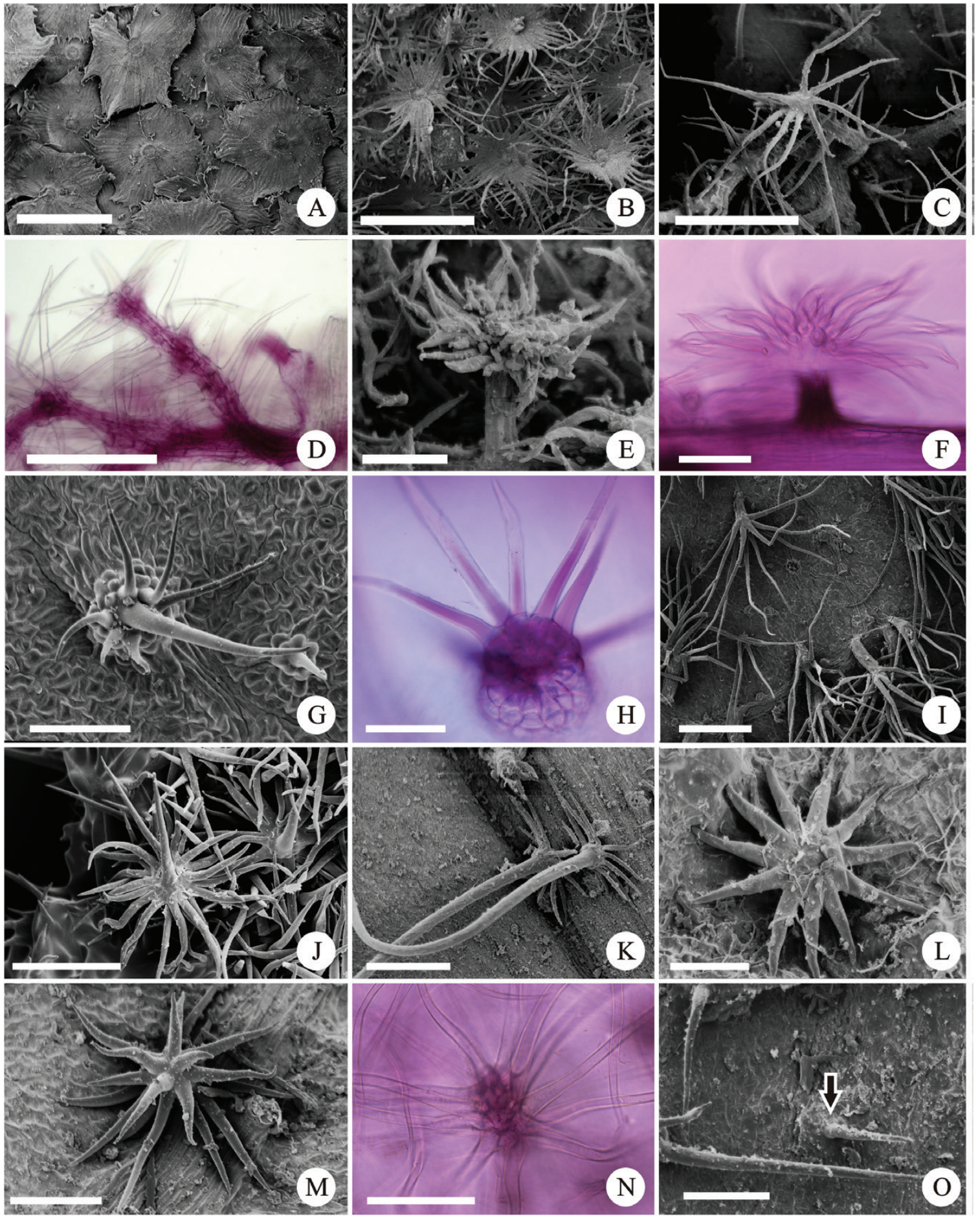

Figure 1. Diversity of non-glandular trichomes in Croton. A, B. Lepidote trichomes; A. C. cupreatus; B. C. urucurana-1; C, D. Dendritic trichomes in C. vulnerarius; E, F. Rosulate trichomes in C. floccosus; G, H. Fasciculate cushion-shaped in C. speciosus; I. Stipitate-stellate trichomes in C. alchorneicarpus; J. Stipitate-stellate porrect trichomes in C. bonplandianus; K. Appressed-stellate porrect trichomes in C. redolens; K. L. Appressed-stellate trichomes in C. piptocalyx; M, N. Multiradiate trichomes in C. hibiscifolius; O. Simple trichomes in C. coriaceus. Bars: $60 \mu \mathrm{m}$ (L); $100 \mu \mathrm{m}$ (E, G, I, M, O); $150 \mu \mathrm{m}(\mathrm{F}, \mathrm{H}) ; 200 \mu \mathrm{m}(\mathrm{J}, \mathrm{K}) ; 300 \mu \mathrm{m}(\mathrm{A}-\mathrm{C}, \mathrm{N}) ; 500 \mu \mathrm{m}(\mathrm{D})$. 


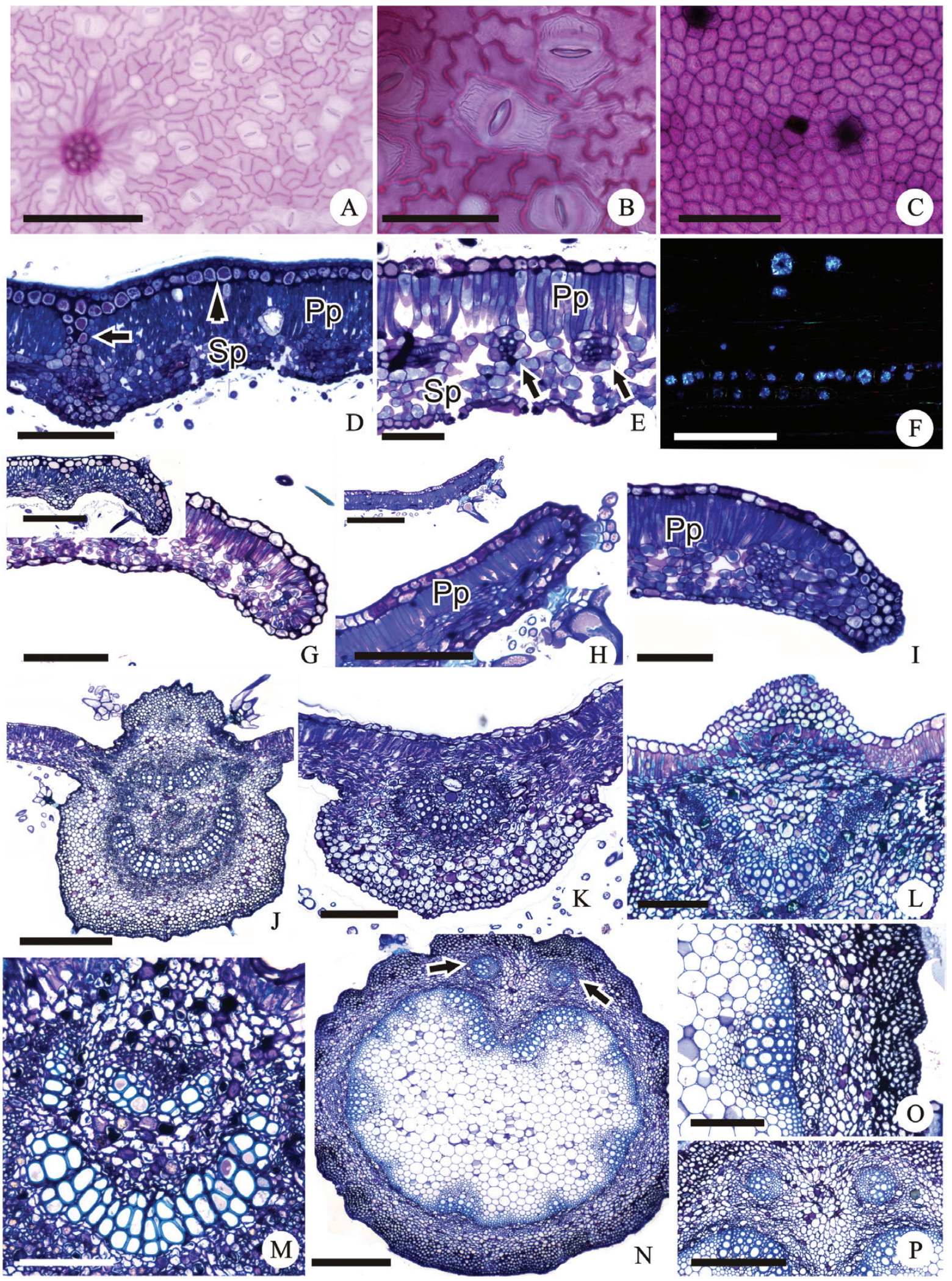




\section{CLUSTER ANALYSIS OF ANATOMICAL CHARACTERS}

The topologies of dendrograms obtained using the DiceSorensen or Jaccard similarity indices were identical in their branching and clustering pattern, and we will use the dendrogram based on the widely used Jaccard's similarity index (Fig. 4) for describing and discussing our main results below. The cluster analysis performed on the 45 characters and 104 specimens examined yielded 44 groups (Fig. 4). These groups were established using similarity values greater or equal to $0.8(\mathrm{~J} \geq 0.8)$ based on their anatomical similarities (a value of 1 indicates $100 \%$ similarity among specimens). We assigned the most appropriate specific taxonomic identity integrating anatomical similarity, shown in the cluster analysis, with information on external morphology, ecological knowledge and geographical data. Thus, of the 44 determined and/or confirmed species, 36 in fact belong to section Cyclostigma, and only six to section Adenophylli, one to section Sampatik and one to section Cupreati (Fig. 4). Some specimens belonging to the same species of Cyclostigma did not group together (e.g. Croton draco, C. coriaceus, C. vulnerarius), so we assigned them a serial number (e.g. draco-1, draco-2). To better explain the overall similarity pattern among specimens, we divided the dendrogram from its base to the tips according to the beginning of the main clusters at different levels. This resulted in three major levels (L1, L2, L3) indicated by dotted vertical lines (Fig. 4). These levels correspond to $0.57,0.60$ and 0.66 similarity values, respectively.

Specimens of sections Sampatik, Cupreati and a group of Adenophylli (C. abutilifolius, C. gracilipes) appear more similar anatomically to section Cyclostigma than specimens of Adenophylli g1 and g2. However, in contrast with the position of the Sampatik and Cupreati clusters, the two species of Adenophylli are nested well in the Cyclostigma group (Fig. 4). Thirteen specimens, marked with a star (Fig. 4), could not be assigned to any known species, but they all have morphological affinities to members of section Cyclostigma. They represent about 11 undescribed species of section Cyclostigma. Some of these undetermined specimens, which appear in four different separate clusters in the dendrogram, were assigned to an informal taxonomic group (the 'medusae' group) based on leaf anatomy and external morphology (Fig. 4).

Subgroups g1 and g2 in Adenophylli were further divided in four subgroups (g6, g7, g8 and g9) based on characteristics, such as acropetiolar EFNs (g6: C. conduplicatus), basilaminar EFNs and appressedstellate trichomes (g7: C. bonplandianus Baill.), appressed-stellate porrect trichomes and absence of associated bundles in the midrib (g8: C. aequatoris), and presence of one to five associated bundles in the midrib (g9: C. ruizianus). The other group of section Adenophylli (C. abutilifolius, $C$. gracilipes) and most species of section Cyclostigma were clustered together essentially because the presence of secretory idioblasts on the abaxial epidermis and stipitate-stellate porrect trichomes (Fig. 4).

\section{DISCUSSION}

\section{SIGNIFICANCE OF LEAF ANATOMICAL FEATURES FOR CROTON SYSTEMATICS}

Anatomical characters were useful for the taxonomic identification of 36 species of section Cyclostigma and for the detection of either intraspecific variation or wrongly identified specimens. Among the character states exclusive to section Cyclostigma and useful to separate species, were the presence of hypodermis, fasciculate cushion-shaped trichomes (both present in five species), dendritic trichomes (restricted to two species) and the absence of nectaries from leaf margin and blade (in all species of section Cyclostigma). On the other hand, some characters states (presence of hypostomatic leaves, paracytic stomata, dorsiventral mesophyll, collateral bundles, druse crystals, basilaminar/acropetiolar extrafloral nectaries, colleters, non-articulated laticifers and stellate trichomes) were common to all Croton spp. sampled. Several studies, focused on one or a couple of species of section Cyclostigma, have also reported

Figure 2. General anatomical features. A-C. Frontal view; D-P. Cross-sections; A. Abaxial epidermis with sinuous anticlinal walls in C. celtidifolius; B. Detail of abaxial epidermis, showing paracitic stomata and cuticle with attenuated stretch in C. macrobothrys; C. Adaxial epidermis with straight to slightly sinuous walls in C. macrobothrys; D. Dorsiventral mesophyll with unistratified epidermis in C. amentiformis, note: hypodermis (arrowhead), bundle-shealth extension (arrow); E. Dorsiventral mesophyll with collateral bundles (arrow) in C. ruizianus; F. Druse crystals under polarized light in the longitudinal section of petiole in C. alchorneicarpus; G, H, I. Leaf margin, G. Revolute in C. conduplicatus, note inset in C. amentiformis; H. Involute in C. bogotanus, Arrowhead: continuous palisade parenchyma; I. Discontinuous palisade parenchyma in C. lechleri; J. Biconvex midrib in C. lechleri; K. Midrib with flat to slightly concave adaxial side in C. conduplicatus; L. Vascular system of midrib with dorsal bundles in C. vulnerarius; M. Vascular system of midrib without dorsal bundles in C. aequatoris; N, O, P. Petiole of $C$. charaguesis; N. General view of petiole with round shape, horseshoe-shaped vascular system and two accessory bundles (arrows); O. Detail of petiole showing epidermis, cortical region and part of vascular system; P. Detail of adaxial side of petiole with two accessory bundles. Pp: palisade parenchyma, Sp: spongy parenchyma, Bars: $100 \mu \mathrm{m}(\mathrm{B}) ; 150 \mu \mathrm{m}$ (D, E, F, I); $200 \mu \mathrm{m}$ $(\mathrm{A}, \mathrm{C}) ; 250 \mu \mathrm{m}(\mathrm{M}) ; 300 \mu \mathrm{m}(\mathrm{G}, \mathrm{H}, \mathrm{K}, \mathrm{L}, \mathrm{O}) ; 600 \mu \mathrm{m}$ (insets Fig. G and H, P); $700 \mu \mathrm{m}(\mathrm{J}) ; 800 \mu \mathrm{m}(\mathrm{N})$. 

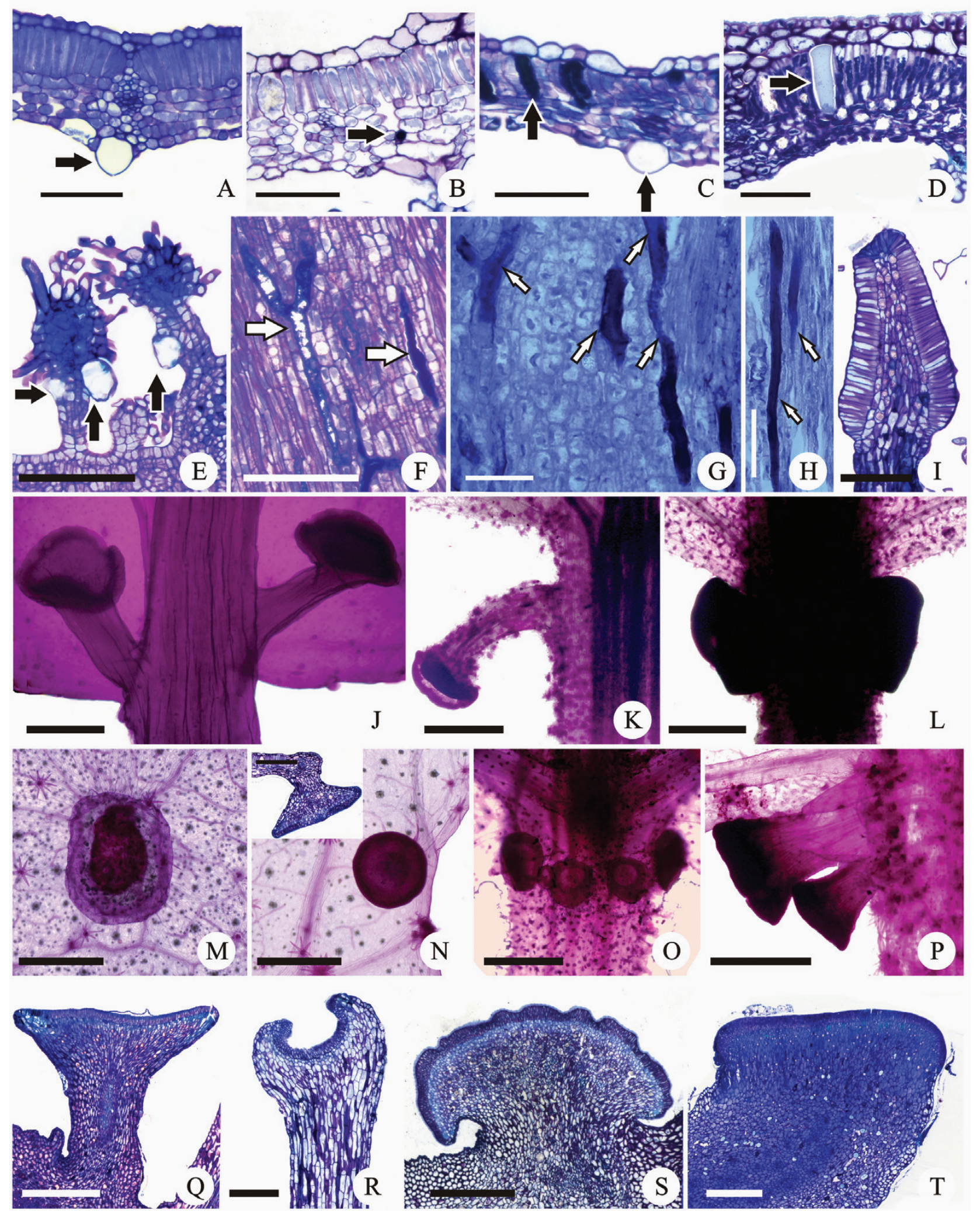
these characters (Rudall, 1994; Webster et al., 1996; Sá-Haiad et al., 2009; Vitarelli et al., 2015; Feio, Riina $\&$ Meira, 2016).

We identified ten types of non-glandular trichomes and confirmed that section Cyclostigma presented all types described by Webster et al. (1996) plus two additional types (fasciculate cushion-shaped and appressed-stellate porrect trichomes), which are here described for the first time in Croton. Previous research about comparative anatomy of Croton (Webster et al., 1996; Senakun \& Chantaranothai, 2010; Liu, Deng \& Liao, 2013) or Crotoneae (Sá-Haiad et al., 2009; Vitarelli et al., 2015) showed that trichome types are useful for taxonomy mostly at the species level. On the other hand, we noted trichome morphology seems to be plastic among the studied species, sometimes even within the same individual. Moreover, we demonstrated that simple trichomes may sometimes correspond to immature stages of a more complex type. Thus, trichome characters should be used with caution for taxonomic purposes in Cyclostigma, and potentially in all other sections of Croton.

In addition, the absence of lepidote trichomes has been used as a character state to distinguish section Cyclostigma from other clades of Croton such as sections Cupreati, Lasiogyne (Klotzsch) Baill. and Lamprocroton (Müll.Arg.) Pax in Engl. \& Prantl (van Ee et al., 2011). However, such trichomes were recently reported in C. macrobothrys Baill. and C. urucurana (Sá-Haiad et al., 2009; Caruzo et al., 2016; Feio, 2016). Here we confirmed that, indeed, all species of section Cyclostigma studied here typically lack these trichomes, except for two specimens of C. urucurana (Pollito-VA-001 and Leitão-Filho-1603), and their presence may vary between populations. Thus, we recommend that these two species be confirmed with additional sampling, given that both taxa have rather large geographical ranges in the Brazilian Atlantic Rain Forest (Caruzo et al., 2016; Santos, Riina \& Caruzo, 2017).

The presence of a hypodermis in six of the 36 species of section Cyclostigma examined and in C.cupreatus is a new report for Croton. Species of section Cyclostigma occur along mountain creeks, edges and gaps of forests, river sides and along roads (Riina et al., 2009; van Ee et al., 2011). Despite the high humidity present in some of these habitats (e.g. cloud forest, river sides), these Croton spp. are exposed to high luminosity and the presence of a hypodermis is clearly advantageous. In fact, all species with a hypodermis occur in montane forest at high elevation in the Andes, but they are not the only species in section Cyclostigma occupying these habitat types.

\section{SYSTEMATIC IMPLICATIONS OF SECRETORY STRUCTURES}

Previous studies of Crotoneae have reported idioblasts producing only lipophilic secretion (e.g. Sá-Haiad et al., 2009; Vitarelli et al., 2015). However, in a detailed study of two species of section Cyclostigma, Feio et al. (2016) also detected polysaccharides, phenolic compounds, alkaloids and proteins, suggesting a richer and more complex nature of the secretion of idioblasts in members of that section.

Vitarelli et al. (2015) described articulated laticifers in leaves and shoots apices in most species of Crotoneae they analysed [i.e. Croton sections Cleodora (Klotzsch) Baill. (12 species) and Lamprocroton (Müll.Arg.) Pax (11 species) and the related genera Astraea Klotzsch (one species) and Brasiliocroton P.E.Berry \& Cordeiro (one species)] and suggested that the articulated type might be widespread in subfamily Crotonoideae. In contrast, non-articulated laticifers were reported by Rudall (1994) for seven Croton spp. (C. antisyphiliticus Mart. ex Müll.Arg., C. conduplicatus, C. heteropleurus Urb., C. megalobotrys Müll.Arg., C. occidentalis Müll. Arg., C. sagraeanus Müll.Arg., C. sylvaticus Hochst. and four undetermined species) belonging to three different clades of Croton [sections Geiseleria (A.Gray) Baill. and Adenophylli and the Old World Croton clade]. Non-articulated laticifers were also found in wood rays of section Cyclostigma (Wiedenhoeft et al., 2009) and additionally in leaves and flowers of two representatives of this section, C. echinocarpus and C. urucurana (Feio et al., 2016). This evidence and our own results suggest that both types of laticifers are probably present in the subfamily, although additional studies including a comprehensive taxon sampling is needed to determine which type is more common in Crotonoideae.

\footnotetext{
Figure 3. Diversity of secretory structures in Croton.A-E. Secretory idioblasts (black arrows); F-H. Laticifers (white arrows); I. Colleter; J-T. Extrafloral nectaries (EFN); A. Idioblasts in the abaxial epidermis in C. alchorneicarpus; B. Idioblasts scattered in the mesophyll in C. rimbachii; C. Idioblasts in the epidermis and palisade parenchyma in C. cupreatus; D. Idioblasts in the palisade parenchyma in C. pseudopopulus; E. idioblasts situated at the base of the trichomes in C. lechleri; F-H. Non-articulated branched laticifers in the shoot apical meristem (white arrows); F. C. amentiformis; G, H. C. celtidifolius; I. Non-vascularized colleter of the standard type in C. bogotanus; J. Stipitate EFN basilaminar in C. macrobothrys; K, L. EFN acropetiolar; K. Stipitate EFN in C. celtidifolius; L. Sessile EFN in Riina-1520; M. Dispersed EFN on the blade in C. piptocalyx; N. Sessile EFN on the leaf margin in C. piptocalyx; O, P. EFN in both acropetiolar and basilaminar; O. Sessile EFN in C. redolens; P. Stipitate EFN in C. pseudopopulus; Q, R. EFN with concave surface in Riina-1592 and C. aequatoris, respectively; S. EFN with convex surface in C. gossypifolius; T. EFN with flat surface in C. cupreatus. Bars: $50 \mu \mathrm{m}(\mathrm{G}, \mathrm{H})$; $150 \mu \mathrm{m}(\mathrm{A}-\mathrm{E}) ; 250 \mu \mathrm{m}(\mathrm{F}, \mathrm{I}) ; 300 \mu \mathrm{m}(\mathrm{R}) ; 800 \mu \mathrm{m}(\mathrm{Q}, \mathrm{S}, \mathrm{T}) ; 0.5 \mathrm{~mm}(\mathrm{M}-\mathrm{O}) ; 1 \mathrm{~mm}(\mathrm{~J}-\mathrm{L}, \mathrm{P})$.
} 


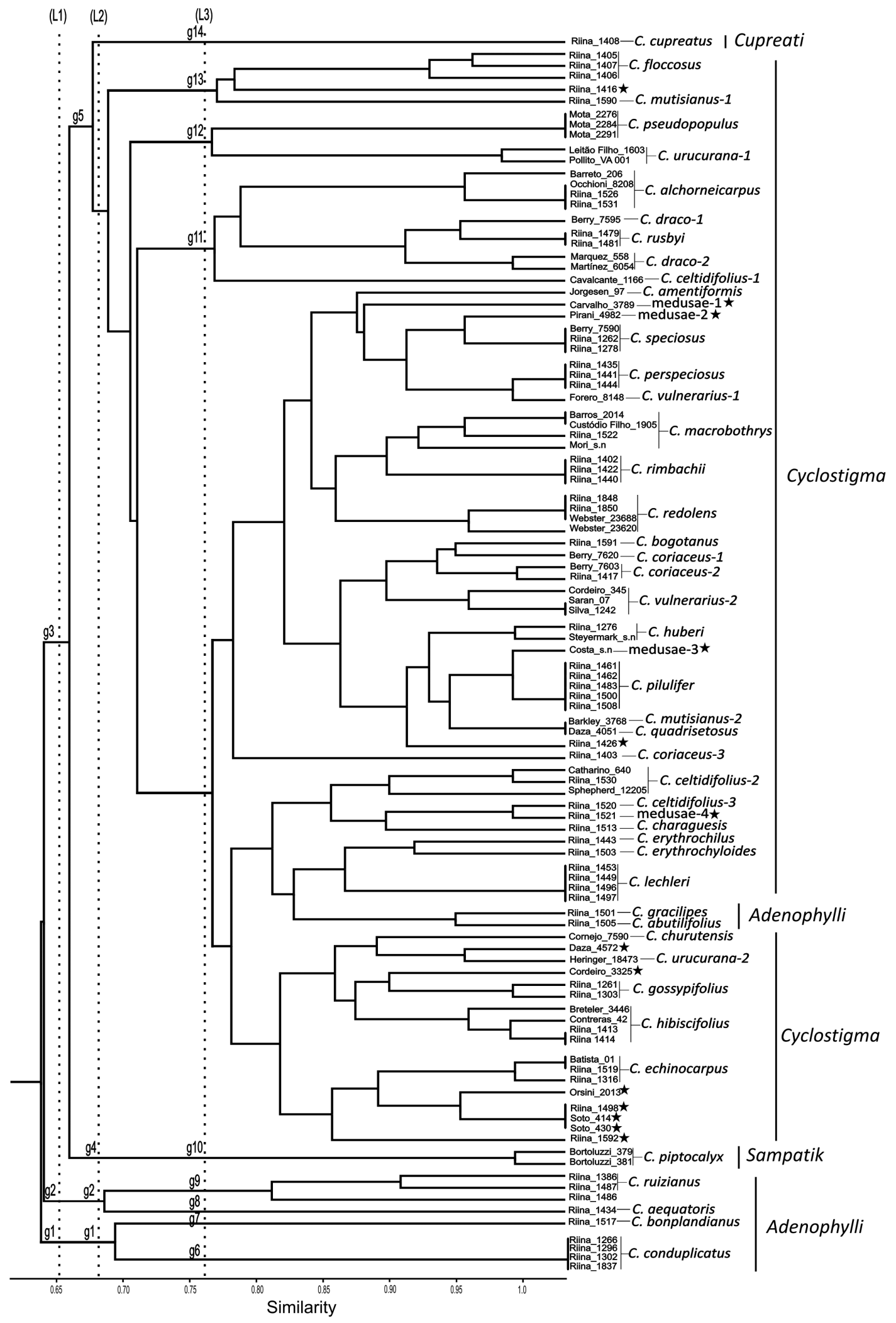

Figure 4. Dendrogram of the 104 specimens analysed using the Jaccard's similarity coefficient. Taxonomic identities assigned to each group are next to specimens. Note: specimens without species name belong to Croton section Cyclostigma (star). Labels L1-3 and g1-14 correspond to levels of similarity and groups (see text). 
Colleters have been previously reported in vegetative (leaves) and reproductive organs in three species of section Cyclostigma (Riina et al., 2015; Feio et al., 2016) and representatives of four other Croton sections, namely C. glandulosus L. (section Geiseleria) (Machado et al., 2015) and sections Alabamenses B.W.van Ee, Lamprocroton, and Cleodora (Vitarelli et al., 2015). This last study also reported colleters in two other genera, Brasiliocroton and Astraea, which are closely related to Croton. There is no consensus about the importance of vascularization in colleters. Carlquist (1969) pointed out that the presence of vascularization is directly related to the size of a structure and not necessarily to its state of development. On the other hand, Thomas (1991) suggested that the vascularization of colleters was more related to the derivation or not of vascular bundles from the organs to which colleters are attached, regardless the size of the structure (Arekal \& Ramakrishna, 1980; Appezzato-da-Glória \& Estelita, 2000). In all studied species, colleters on leaves were non-vascularized and sometimes deciduous (on mature leaves). Deciduous, nonvascularized colleters have been previously reported on the leaves of other Croton spp. (Riina et al., 2015; Vitarelli et al., 2015; Feio et al., 2016). Colleter-deciduousness on mature leaves could be related to the lack of a continuous nourishment in these secretory structures, but this hypothesis needs further investigation.

Structural variation and location of extrafloral nectaries were useful features distinguishing group of species at different levels in the cluster analysis. For example, species of section Adenophylli were separated in three subgroups: one group with sessile EFNs and convex surface (g1); one with stipitate EFNs and concave surface (g2) and one (C. abutilifolius, C. gracilipes) clustering with members of section Cyclostigma. The presence of nectaries scattered on the blade and along the leaf margin (alternating with colleters) confirmed the classification of Riina et al. (2009), which removed C. piptocalyx from section Cyclostigma sensu Webster (1993).

\section{DELIMITATION OF GROUPS AND TAXONOMIC IMPLICATIONS}

Specimens of sections Sampatik, Cupreati and a group of Adenophylli (C. abutilifolius, C. gracilipes) appear more similar anatomically to section Cyclostigma than specimens of Adenophylli $\mathrm{g} 1$ and g2. This gives an indication of the homoplasious nature of the anatomical characters used in this study, which is similar to the pattern found with external morphological characters (Riina et al., 2009). The morphoanatomical characters alone will not be enough to separate groups at the sectional level in the genus Croton. However, our results show that the use of anatomical characters could facilitate taxonomic delimitation at the species level in sections of Croton, and it is possible that using anatomical and morphological characters in combination could be even more useful for establishing species limits. There is a recent study establishing species limits in Croton occurring in a region of the northern Andes (Luján, León \& Riina, 2015), but these authors only analysed vegetative morphological characters.

Specimens Soto-414 and Soto-430 are from the same locality in Bolivia. They are morphologically identical and were initially identified based on external morphology as $C$. aff. urucurana. These two specimens clustered with Riina-1498, which was initially identified as $C$. tyndaridum Croizat. It is possible that these three specimens belong to the same species given their high similarity (100\%) in anatomical characters. Riina-1498 is problematic because it comes from a cultivated plant in the city of Lima (Peru) and there were no records of its provenance, and its identification as $C$. tyndaridum was always questionable, since $C$. tyndaridum is only known from the type locality (Rio Perené, Junín, Peru). Because Soto-414 and Soto-430 did not group with any of the C. urucurana groups, and the uncertainty regarding the identity and origin of Riina-1498, we did not assign any name to this group and consider it as an unknown and probably undescribed species.

Croton draco-1 (Berry-7595), despite being originally identified as $C$. draco based on morphology, clustered with C. rusbyi Britton ex Rusby and not with C. draco-2 (Marquez-558 and Martinez-6054). Croton draco-1 has a bundle-sheath extension, dendritic trichomes and revolute margin, which are features absent in C. draco2. Croton draco is another widespread and variable species occurring from Mexico to Panama (Webster \& Burch, 1968; Webster \& Huft, 1988) and, given its wide geographical range, it would have been desirable to have a better sampling of it. Our results show that there might be at least two morphotypes that could be easily separated by anatomical characters. This group obviously merits further investigation using anatomy, morphology and molecular data and a better sampling across its entire range.

Croton mutisianus-1 and C. mutisianus-2 also did not cluster together as expected. Instead, C. mutisianus-2 clustered with C. quadrisetosus Lam. It is possible that this grouping is an artefact since C. mutisianus-2 has the highest percentage of missing data $(21 \%)$ in our matrix. In fact, C. mutisianus-2 (Barkley-3768) was a poor sample and it was not possible to obtain information about EFN and stem apex to characterize the type of laticifers. External morphology does not support this grouping either, since C. mutisianus-2 and C. quadrisetosus have many differences in floral morphology (e.g. flowers with long pedicels, and stigmas bifid and terete in C. mutisianus vs. flowers sessile to subsessile and stigmas multifid 
with expanded and flattened tips in C. quadrisetosus). In addition, $C$. mutisianus is widespread in montane forests of Colombia, and C. quadrisetosus is only known from montane forests of Peru (Berry et al., 2015).

Unexpected grouping patterns, similar to those discussed above, were found for specimens previously identified using external morphology as C. celtidifolius, C. vulnerarius and C. coriaceus. Specimens from these three species show relatively low levels of similarity in anatomical characters appearing in separate groups of the dendrogram. It is possible that in some cases the species are indeed more polymorphic in relation to anatomical characters than to characters from external morphology. However, the limited sampling prevents us from using anatomical data alone to further subdivide such species, especially because the external morphology does not support the observed clustering pattern based on anatomy. All these taxa need further investigation using a broader sampling across their geographical range and integration of anatomy and morphology in the evaluation of species limits.

Our study provides additional characters that can contribute to clarify the taxonomic affinities of species in section Cyclostigma, and it gives support to the taxonomic position of the section adopted by Riina et al. (2009) and van Ee et al. (2011). As with external morphology (Riina et al., 2009), section Cyclostigma can also be characterized by a suite of anatomical characters and so far only one anatomical wood character (secondary xylem rays containing nonarticulated laticifers) has been identified as a possible synapomorphy for the section (Wiedenhoeft et al., 2009).

\section{CONCLUSIONS AND FUTURE WORK}

Although we did not find an anatomical character present in all members of section Cyclostigma, the use of a suite of characters was useful to group specimens based on their similarities and to confirm and/or to determine taxonomic identities at the species level in most cases. However, we also recognize the limitation of these characters in several taxa for which taxonomic resolution was not achieved. The presence of different types of stellate trichomes, non-articulated laticifers, absence of marginal EFNs and the lack of lepidote trichomes can be used in combination to define section Cyclostigma anatomically. Three new anatomical features were described for Croton: hypodermis, fasciculate cushion-shaped trichomes and appressedstellate porrect trichomes. Our results do not fully support the hypothesis of a widespread occurrence of articulated laticifers in Crotonoideae, but future studies for re-evaluating laticifers in this subfamily are necessary and should include analyses of their ontogeny and the nature of their secretions. Finally, we highlight the partial utility of anatomical characters at the species level and the need of using them along with other characters in an integrative taxonomic framework.

\section{ACKNOWLEDGEMENTS}

ACF thanks FAPEMIG for the scholarship in Brazil during her doctoral degree, the CAPES foundation through PDSE (99999.009518/2014-02) supporting her stay at the Real Jardín Botánico-CSIC (Madrid) and the Programa de Capacitação Institucional (MPEG/ MCTI) for the current CNPq research grant. RMSAM was supported by CNPq (477867/2013-8). RR was supported by a Visiting Scholar Fellowship to Brazil funded by FAPEMIG (CRA-BPV-00043-14) and CNPq research grant (477867/2013-8). Additional support was provided by Centro de Ciências Ambientais Floresta Escola (SECTES/UNESCO/HidroEX/FAPEMIG). We are grateful to two reviewers and the associate editor for their valuable suggestions and critical comments to earlier versions of this manuscript.

\section{REFERENCES}

Appezzato-da-Glória B, Estelita MEM. 2000. Development, structure and distribution of colleters in Mandevilla illustris and M. velutina (Apocynaceae). Revista brasileira de Botânica 23: 113-120.

Arekal GD, Ramakrishna TM. 1980. Extrafloral nectaries of Calotropis gigantea and Wattakaka volubilis. Phytomorphology 30: 303-306.

Berry P, Riina R, van Ee B. 2015. Croton mutisianus Kunth. In: Bernal R, Gradstein SR, Celis M, eds. Catálogo de plantas y líquenes de Colombia. Instituto de Ciencias Naturales, Universidad Nacional de Colombia, Bogotá. Available at: http://catalogoplantasdecolombia.unal.edu.co.

Borges JR, King SR. 2000. Croton lechleri, sustainable utilization of an Amazonian pioneer species. Medicinal Plant Conservation 6: 24-26.

Bozzola JJ, Russel LD. 1992. Electron microscopy. Boston: Jones and Bartlett Publishers.

Carlquist S. 1969. Toward acceptable evolutionary interpretations of floral anatomy. Phytomorphology 19: 332-362.

Caruzo RFS, Santos RF, Feio AC, Meira RMSA, Riina R. 2016. Redefinition of Croton macrobothrys (Euphorbiaceae), a tree species from the Brazilian Atlantic Forest, with the description of a new subspecies. Phytotaxa 273: 51-58.

Christenhusz MJ, Fay MF, Chase MW. 2017. Plants of the world: an illustrated encyclopedia of vascular plants. Kew and Chicago: Kew Publishing/University of Chicago Press.

Evert RF. 2006. Esau's plant anatomy. Meristems, cells, and tissues of the plant body - their structure, function, and development, 3th edn. Hoboken: Wiley.

Feio AC. 2016. Croton sect. Cyclostigma (Euphorbiaceae): novidades anatômicas e taxonômicas. PhD Thesis, Universidade Federal de Viçosa, Minas Gerais. 
Feio AC, Riina R, Meira RMSA. 2016. Secretory structures in leaves and flowers of two dragon's blood Croton (Euphorbiaceae): new evidence and interpretations. International Journal of Plant Sciences 177: 511-522.

Feio AC, Ore-Rengifo MI, Berry PE, Riina R. 2018. Four new species of dragon's blood Croton (Euphorbiaceae) from South America. Systematic Botany (in press).

Haber EA, Kainulainen K, Van Ee BW, Oyserman BO, Berry PE. 2017. Phylogenetic relationships of a major diversification of Croton (Euphorbiaceae) in the western Indian Ocean region. Botanical Journal of the Linnean Society 183: 532-544.

Hammer $\emptyset$, Harper DAT, Ryan PD. 2001. PAST: paleontological statistics software package for education and data analysis. Palaeontologia Electronica 4: 1-9.

Jones K. 2003. Review of sangre de drago (Croton lechleri) - a South American tree sap in the treatment of diarrhea, inflammation, insect bites, viral infections, and wounds: traditional uses to clinical research. The Journal of Alternative and Complementary Medicine 9: 877-896.

Kaiser E. 1880. Verfahren zur Herstellung einer tadellosen Glycerin-gelatine. Botanisch Zentralblatt, Stuttgart 180: 25-26.

Liu HF, Deng YF, Liao JP. 2013. Foliar trichomes of Croton L. (Euphorbiaceae: Crotonoideae) from China and its taxonomic implications. Bangladesh Journal of Plant Taxonomy 20: 85-94.

Luján M, León Y, Riina R. 2015. Synopsis of Croton (Euphobiaceae) in the Andes of Mérida, Venezuela. Caldasia 37: 73-90.

Machado SR, Paleari LM, Paiva EAS, Rodrigues TM. 2015. Colleters on the inflorescence axis of Croton glandulosus (Euphorbiaceae): structural and functional characterization. International Journal of Plant Sciences 176: 86-93.

Meira RMSA, Martins FM. 2003. Inclusão de material herborizado em metacrilato para estudos de anatomia vegetal. Revista Árvore 27: 109-112.

Metcalfe CR, Chalk L. 1979. Anatomy of the dicotyledons: systematic anatomy of the leaf and stem, Vol. I, 2nd edn. Oxford: Oxford University Press.

Metcalfe CR, Chalk L. 1983. Anatomy of the dicotyledons, Vol. 2, 2nd edn. Oxford: Clarendon Press.

Meza EN. 1999. Nombres aborigenes peruanos de las especies de Croton que producen el latex denominado 'sangre de grado'. In: Mesa EN, ed. Desarrollando nuestra diversidad cultural: 'sangre de grado' y el reto de su producción en el Peru. San Marcos: Universidad Nacional Mayor de San Marcos, Fondo Editorial, 25-44.

O'Brien TP, Feder N, McCully ME. 1965. Polychromatic staining of plant cells walls by toluidine blue O. Protoplasma 59: $368-373$.

Riina R, Berry PE, Cornejo X. 2007. A new species of 'sangre de drago' (Croton section Cyclostigma, Euphorbiaceae) from coastal Ecuador. Brittonia 59: 97-101.

Riina R, Berry PE, van Ee BW. 2009. Molecular phylogenetics of the dragon's blood Croton section Cyclostigma (Euphorbiaceae): a polyphyletic assemblage unraveled. Systematic Botany 34: 360-374.

Riina R, Vigo MA, Cerón CE. 2014. Croton condorensis: an enigmatic new species of Euphorbiaceae from southern Ecuador. Phytotaxa 164: 154-158.
Riina R, Cumbicus N, Feio AC, Cerón CE, Meira RMSA, Berry PE. 2015. A new species of dragon's blood Croton (Euphorbiaceae) from South America with singular inflorescences. Webbia 70: 187-192.

Rudall PJ. 1994. Laticifers in Crotonoideae (Euphorbiaceae): homology and evolution. Annals of the Missouri Botanical Garden 81: 270-282.

Sá-Haiad B, Serpa-Ribeiro ACC, Barbosa CN, Pizzini D, Leal DO, Senna-Valle L, Santiago-Fernandes LDR. 2009. Leaf structure of species from three closely related genera from tribe Crotoneae Dumort. (Euphorbiaceae s.s., Malpighiales). Plant Systematics and Evolution 283: 179-202.

Salatino A, Salatino MLF, Negri G. 2007. Traditional uses, chemistry and pharmacology of Croton species (Euphorbiaceae). Journal of the Brazilian Chemical Society 18: 11-33.

Santos RF, Riina R, Caruzo MBR. 2017. Diversity of arborescent lineages of Crotoneae (Euphorbiaceae) in the Brazilian Atlantic Rain Forest. Plant Systematics and Evolution 303: 1467-1497

Senakun C, Chantaranothai P. 2010. A morphological survey of foliar trichomes of Croton L. (Euphorbiaceae) in Thailand. Thai Forest Bulletin, Botany 38: 167-172.

Shobe WR, Lersten NR. 1967. A technique for clearing and staining gymnosperm leaves. Botanical Gazette 128: 150-152.

Smith FH, Smith EC. 1942. Anatomy of the inferior ovary of Darbya. American Journal of Botany 29: 464-471.

Thiers B. 2017. [continuously updated]. Index Herbariorum: a global directory of public herbaria and associated staff. New York: New York Botanical Garden's Virtual Herbarium. Available at: http://sweetgum.nybg.org/science/ih/.

Thomas V. 1991. Structural, functional and phylogenetic aspects of the colleter. Annals of Botany 68: 287-305.

van Ee BW, Riina R, Berry PE. 2011. A revised infrageneric classification and molecular phylogeny of new world Croton (Euphorbiaceae). Taxon 60: 791-823.

Vitarelli NC, Riina R, Caruzo MBR, Cordeiro I, FuertesAguilar J, Meira RMSA. 2015. Foliar secretory structures in Crotoneae (Euphorbiaceae): diversity, anatomy, and evolutionary significance. American Journal of Botany 12: 833-847.

Webster GL. 1993. A provisional synopsis of the sections of the genus Croton (Euphorbiaceae). Taxon 42: 793-823.

Webster GL, Burch D. 1968. Euphorbiaceae. In: Flora of Panama. Annals of the Missouri Botanical Garden 54: 211-350.

Webster GL, Huft MJ. 1988. Revised synopsis of Panamanian Euphorbiaceae. Annals of the Missouri Botanical Garden 75: 1087-1144.

Webster GL, Del-Arco Aguilar MJ, Smith BA. 1996. Systematic distribution of foliar trichome types in Croton (Euphorbiaceae). Botanical Journal of the Linnean Society 121: 41-57.

Wiedenhoeft AC, Riina R, Berry PE. 2009. 'Ray-intrusive' laticifers in species of Croton section Cyclostigma (Euphorbiaceae). IAWA Journal 30: 135-148. 
Appendix 1. List of species with their most recent taxonomic identification (previous to this study) and voucher information. Herbarium acronyms in parentheses according to Thiers (2016).

\begin{tabular}{|c|c|}
\hline Species & Specimen number, collector and collection number (herbarium) \\
\hline \multicolumn{2}{|l|}{ Croton section Cyclostigma } \\
\hline C. alchorneicarpus Croizat & $\begin{array}{l}\text { 1: Riina } 1526(\mathrm{MICH}) ; 2 \text { : Barreto } 206 \text { (MG); 3: Riina } 1531 \text { (MICH); 4: Occhioni } \\
8208(\mathrm{MBM})\end{array}$ \\
\hline C. amentiformis Riina & 5: Jorgensen 97 (MO) \\
\hline C. bogotanus Cuatrec. & 6: Riina $1591(\mathrm{MICH})$ \\
\hline C. aff. celtidifolius / pseudopopulus & 7: Cavalcante $1166(\mathrm{MG})$ \\
\hline C. celtidifolius Baill. & $\begin{array}{l}\text { 8: Catharino } 640 \text { (MG); 9: Riina } 1520 \text { (MICH); 10: Riina } 1530 \text { (MICH); 11: } \\
\text { Shepherd } 12205(\mathrm{MG})\end{array}$ \\
\hline C. charaguensis Standl. & 12: Riina $1513(\mathrm{MICH})$ \\
\hline C. churutensis Riina \& Cornejo & 13: Cornejo 7590 (MICH) \\
\hline C. coriaceus Kunth & 14: Berry $7603(\mathrm{MICH})$; 15: Riina $1403(\mathrm{MICH})$; 16: Riina $1417(\mathrm{MICH})$ \\
\hline C. aff. coriaceus Kunth & 17: Berry $7620(\mathrm{MICH})$ \\
\hline C. draco Schltdl. & 18: Berry 7595 (MICH); 19: Marquez 558 (MBM); 20: Martínez 6054 (MBM) \\
\hline C. echinocarpus Müll.Arg. & 21: Riina 1316 (MICH); 22: Riina 1519 (MICH); 23: Batista 01 (VIC) \\
\hline C. erythrochyloides Croizat & 24: Riina $1503(\mathrm{MICH})$ \\
\hline C. fastuosus Baill. & 25: Costa s/n (BHCB) \\
\hline C. floccosus B.A.Sm. & 26: Riina $1405(\mathrm{MICH})$; 27: Riina $1406(\mathrm{MICH})$; 28: Riina $1407(\mathrm{MICH})$ \\
\hline C. glaziovii Müll.Arg. & 29: Riina 1521 (MICH) \\
\hline C. gossypiifolius Vahl & 30: Riina 1261 (MICH); 31: Riina $1303(\mathrm{MICH})$ \\
\hline C. hibiscifolius Kunth ex Spreng. & $\begin{array}{l}\text { 32: Breteler } 3446(\mathrm{MG}) \text {; 33: Contreras } 042(\mathrm{MICH}) \text {; 34: Riina } 1413(\mathrm{MICH}) \text {; } 35 \text { : } \\
\quad \text { Riina } 1414(\mathrm{MICH})\end{array}$ \\
\hline C. aff. hibiscifolius & 36: Riina 1592 (MA); 37: Orsini 2013-13 (MYF) \\
\hline C. huberi Steyerm. & 38: Riina 1276 (MICH); 39: Steyermark s.n. (MG) \\
\hline C. lechleri Müll.Arg. & $\begin{array}{l}\text { 40: Riina } 1443(\mathrm{MICH}) \text {; } 41 \text { : Riina } 1449(\mathrm{MICH}) \text {; } 42 \text { : Riina } 1496(\mathrm{MICH}) \text {; } 43 \text { : } \\
\quad \text { Riina } 1497(\mathrm{MICH})\end{array}$ \\
\hline C. aff. lechleri Müll.Arg. & 44: Riina $1453(\mathrm{MICH})$ \\
\hline C. macrobothrys Baill. & $\begin{array}{l}\text { 45: Barros } 2014(\mathrm{MG}) \text {; 46: Custodio Filho } 1905 \text { (MG); 47: Mori s.n. (MG); 48: } \\
\quad \text { Riina } 1522(\mathrm{MICH})\end{array}$ \\
\hline C. aff. medusae Müll.Arg. & 49: Pirani 4982 (SPF) \\
\hline C. aff. mutisianus Kunth & 50: Riina 1590 (UEN, MA) \\
\hline C. mutisianus Kunth & 51: Barkley 3768 (MBM) \\
\hline C. perspeciosus Croizat & 52: Riina $1435(\mathrm{MICH})$; 53: Riina $1441(\mathrm{MICH})$; 54: Riina $1444(\mathrm{MICH})$ \\
\hline C. pilulifer Rusby & 55: Riina 1500 (MICH); 56: Riina 1508 (MICH) \\
\hline C. aff. pilulifer Rusby & 57: Riina $1461(\mathrm{MICH})$; 58: Riina $1462(\mathrm{MICH})$; 59: Riina $1483(\mathrm{MICH})$ \\
\hline C. plagiograptus Müll.Arg. & 60: Carvalho 3789 (MBM) \\
\hline C. pseudopopulus Baill. & 61: Mota 2276 (VIC); 62: Mota 2284 (VIC); 63: Mota 2291 (VIC) \\
\hline C. quadrisetosus Lam. & 64: Daza $4051(\mathrm{E})$ \\
\hline C. redolens Pittier & 65: Riina 1848 (MICH); 66: Riina 1850 (MICH); 67: Webster $23688(\mathrm{MICH})$ \\
\hline C. aff. redolens Pittier & 68: Webster 23620 (MICH) \\
\hline C. rimbachii Croizat & 69: Riina $1402(\mathrm{MICH})$; 70: Riina $1422(\mathrm{MICH})$; 71: Riina $1440(\mathrm{MICH})$ \\
\hline C. rusbyi Britton ex Rusby & 72: Riina 1479 (MICH); 73: Riina 1481 (MICH) \\
\hline C. sp1 & 74: Daza $4572(\mathrm{E})$ \\
\hline C. sp2 & 75: Riina 1426 (MICH) \\
\hline C. sp3 & 76: Riina $1416(\mathrm{MICH})$ \\
\hline C. speciosus Müll.Arg. & 77: Berry $7590(\mathrm{MICH})$; 78: Riina $1262(\mathrm{MICH})$; 79: Riina $1278(\mathrm{MICH})$ \\
\hline C. tyndaridum Croizat & 80: Riina 1498 (MICH) \\
\hline C. urucurana Baill. & 81: Heringer 18473 (MG); 82: Leitão-Filho-1603 (MG); 83: Pollito-VA-001 (MG) \\
\hline C. aff. urucurana Baill. & 84: Cordeiro 3325 (SP); 85: Soto 430 (USZ) \\
\hline C. aff. urucurana/lechleri & 86: Soto 414 (USZ) \\
\hline C. vulnerarius Baill. & $\begin{array}{l}\text { 87: Cordeiro } 345 \text { (MG); 88: Forero } 8148 \text { (MG); 89: Saran } 07 \text { (MG); 90: Silva } \\
1242 \text { (VIC) }\end{array}$ \\
\hline
\end{tabular}


Appendix 1. Continued

Species

Croton section Adenophylli

C. abutilifolius Croizat

C. aequatoris Croizat

C. bonplandianus Baill.

C. conduplicatus Kunth

C. gracilipes Baill.

C. ruizianus Müll.Arg.

Croton section Sampatik

C. piptocalyx Müll. Arg.

Croton section Cupreati

C. cupreatus Croizat
Specimen number, collector and collection number (herbarium)

91: Riina 1505 (MA)

92: Riina 1434 (MA)

93: Riina 1517 (LPB)

94: Riina 1266 (VEN); 95: Riina 1302 (VEN); 96: Riina 1296 (MICH); 97: Riina 1837 (MA)

98: Riina 1501 (MA)

99: Riina 1386 (MICH); 100: Riina 1486 (MICH); 101: Riina 1487 (MICH)

102: Bortoluzzi 379 (VIC); 103: Bortoluzzi 381 (VIC)

104: Riina 1408 (MA) 


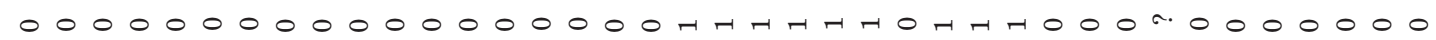

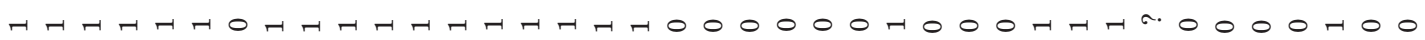
000000000000000000000000000000000000000

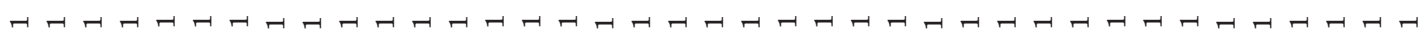
000000000000000000000000000000000000000

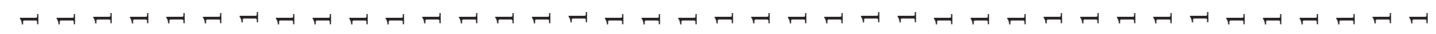

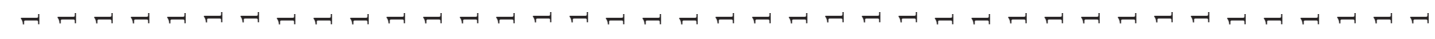

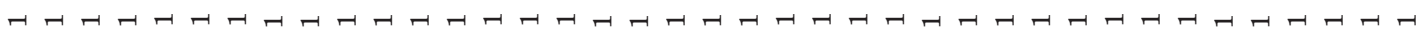
000000000000000000000000000000000000000

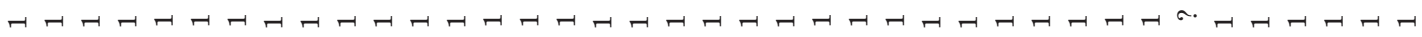

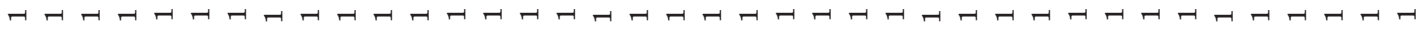
000000000000000000000000000000000000000 000000000000000000000000000000000000000 $0000000000000000000000000 H-H 00000000000$

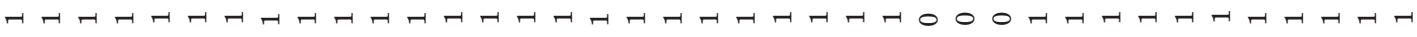

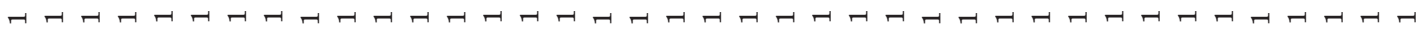

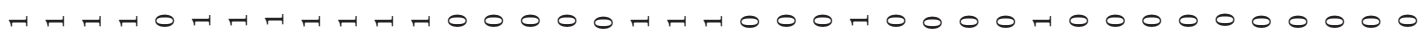

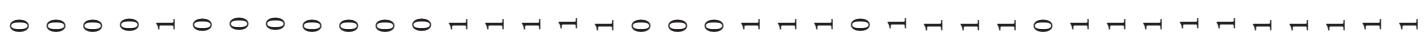

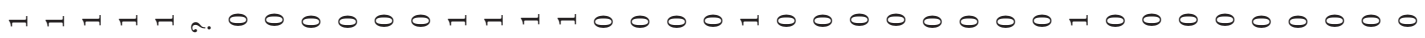
00000 a 000000000000000000000000000000000

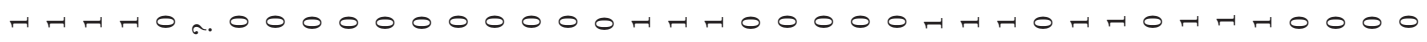
00000 a $0000 \pi 00000000 r 0000000000000000000$

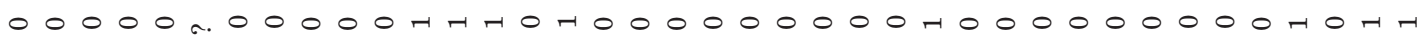

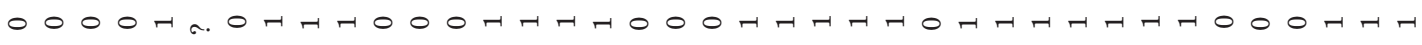

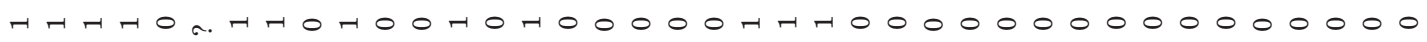
00000 a. $00000000-10000000000000-100000000-r$ $00000 h^{-t} 0000000000 \pi 000000000000000000000$ 00000 r $0000000000000 H_{H}$ 00000 a 000000000000000000000000000000000 $000000-10000000-1000000000000000000000000$

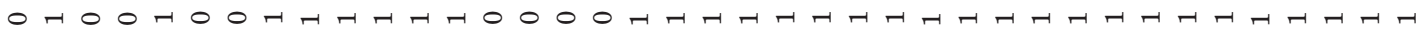

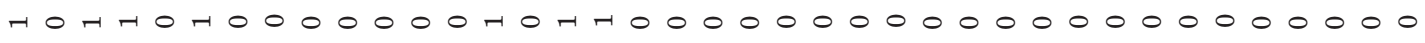

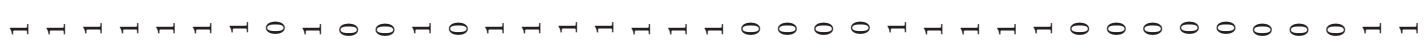

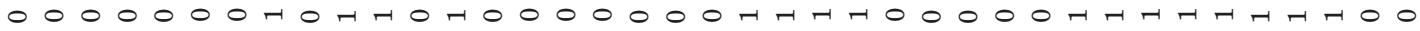
000000000000000000000000000000000000000 000000000000000000000000000000000000000

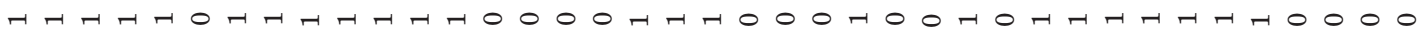

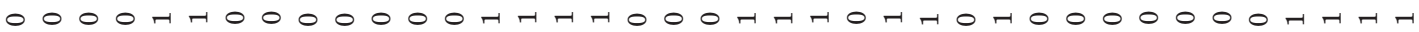
000000000000000000000000000000000000000

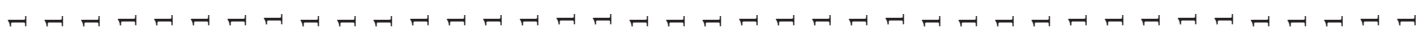

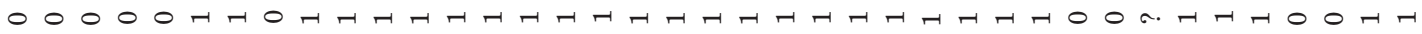

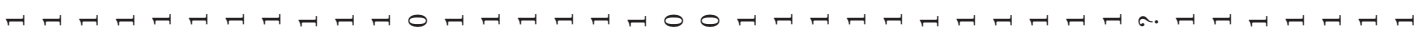
$0000-10400000000000000000000000000000400$

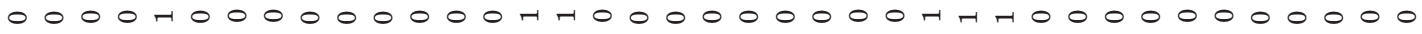

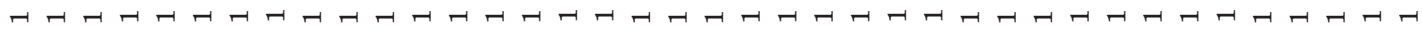

† ๓ ๓ 


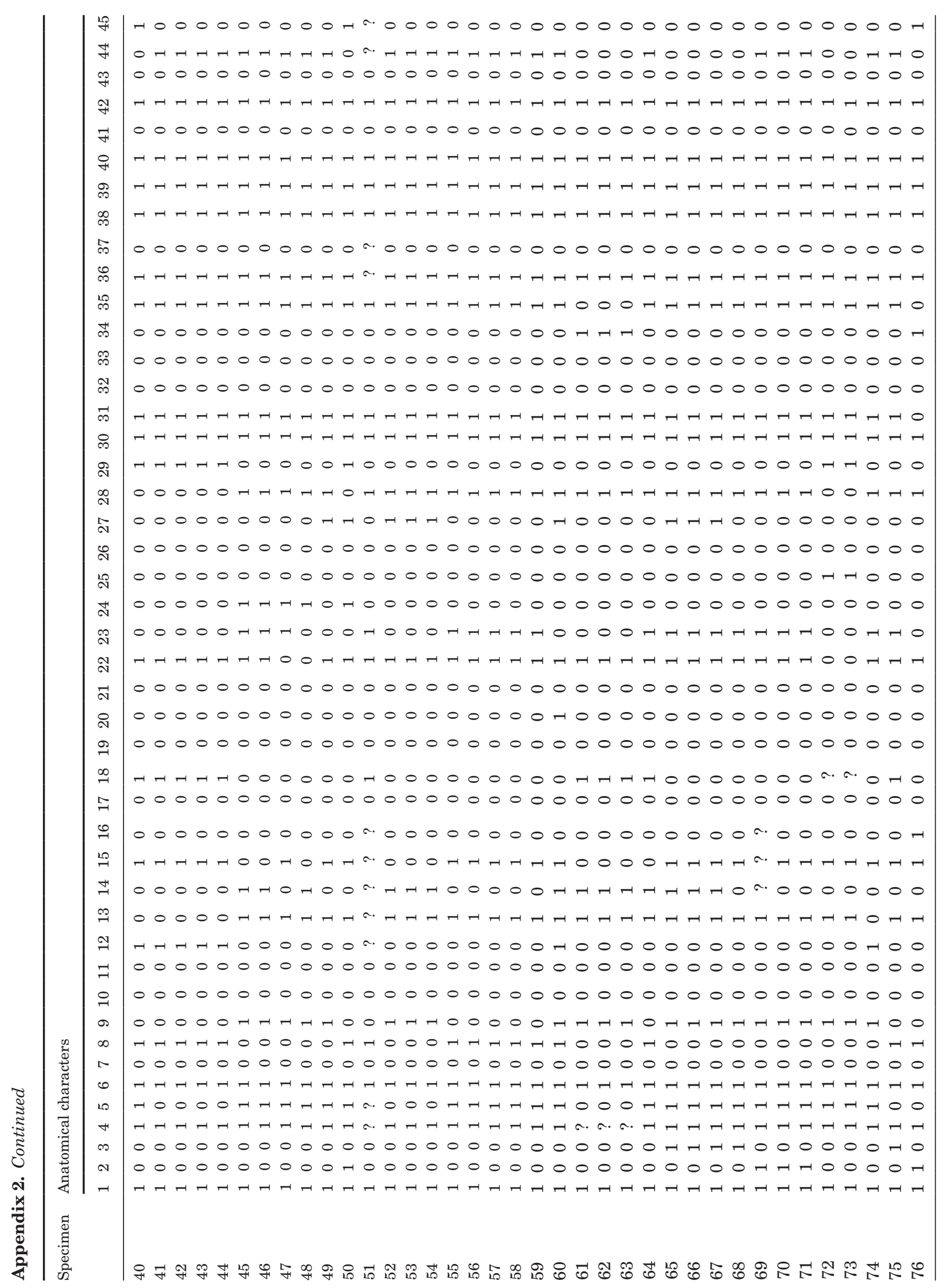


I 10000000000000000000000000000 A

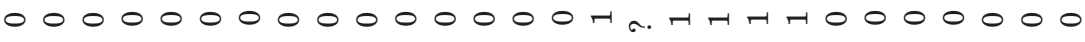

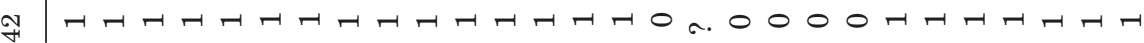
F 0000000000000000 a H H H

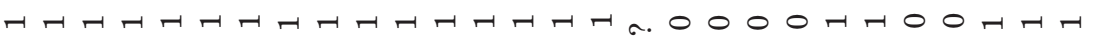

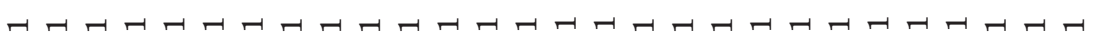

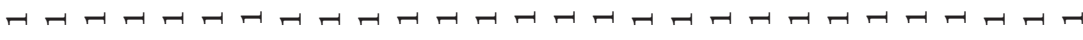
$000000^{r} 000000000000000000 \% 00$

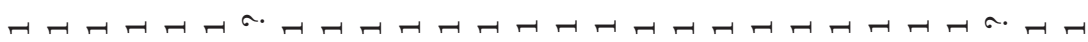
H $00000-100000000$ r. 00 r. 00000000 $000000000000000 \pi \cdot 00$ r. $0000000 \mathrm{H}$ 000000000000000 r. 00 r. 00000000

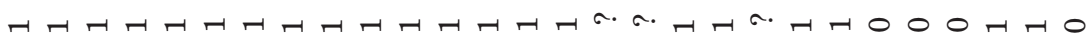
ન 00000000000 a 00 O

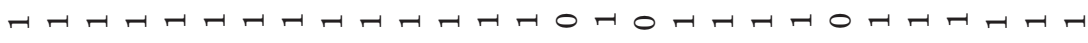
$H-H 0000 H^{-1} 00 H_{H}-10000000000000000$ 0000000000000000000000000000 $00000000000000000000000000-1$ $0000000000000000-100000000-1-0$ $0000-10000000000-1000000000 H^{-1} 0$

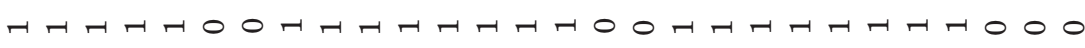
0000000000000000000000000000 H $H$ $000000000070 H-1,0000000000000$ 0000000000000000000000000000 $00000 H-1000000000000000 H 0 H 00$ H $00000000000000000000000-1000-1$

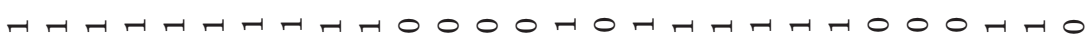

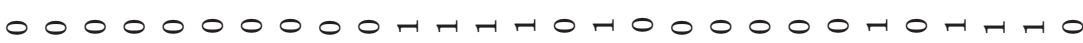
$H-H 00$ a r

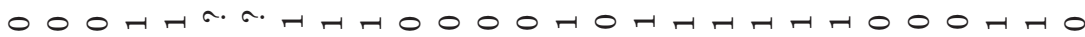
$0000000000000000000000000-1-1-1$ $0000000000000000000000000-4 H^{-1}$

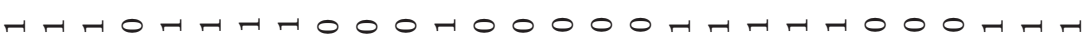

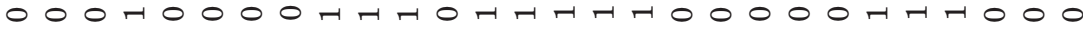
0000000000000000000000000000

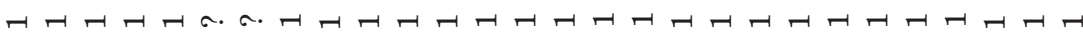

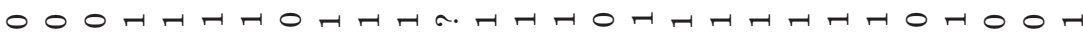

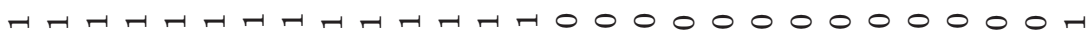

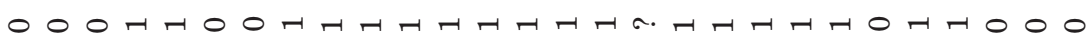
$000000000000000000000000000 H^{-1}$

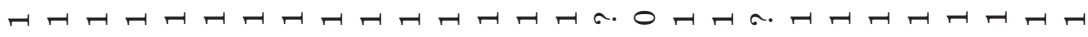

솓 尺 